\title{
Plasminogen assay by a haemagglutination inhibition technique
}

\author{
C. A. LUDLAM AND P. C. DAS \\ From the Regional Transfusion Centre and Blood Products Unit, Royal Infirmary, Edinburgh
}

SYNOPSIS Formaldehyde or gluteraldehyde cells treated with tannic acid were coated with plasminogen. These cells are agglutinated by plasminogen antiserum and this reaction can be quantitatively inhibited by purified plasminogen, plasma, and euglobulin. Correlation between this haemagglutination assay and a caseinolytic method is good. The sensitivity of the technique is high and compares favourably with other immunological methods and is approximately 10 times more sensitive than caseinolytic assays. The merits of this type of assay are discussed.

Plasminogen is an essential component of the fibrinolytic system (Sherry, 1968), and a knowledge of its plasma concentration is useful in pathological coagulation-fibrinolytic states, such as during fibrinolytic therapy, disseminated intravascular coagulation, and fibrinolytic states associated with pregnancy (McKay, 1965; Pechet, 1965; Basu, 1969). Routine techniques for the assay of plasminogen depend upon its activation to plasmin which has endopeptidase activity; this can be measured using various techniques, including caseinolysis, fibrin plates, esterase activity with synthetic esters, and clot lysis (Troll, Sherry, and Wachmann, 1954; Robert, 1958; Alkjaersig, Fletcher, and Sherry, 1959; Berg, Korsan-Bengtsen, and Ygge, 1966; Wolf, 1968; Ygge, 1970).

Recent work has shown the difficulties in obtaining both maximum activation of plasminogen and minimum inhibition of the plasmin formed by naturally occurring antiplasmins. Since the development of methods for preparing very pure plasminogen, and hence specific antiserum, attempts have been made to assay this protein by immunological methods (Ganrot and Niléhn, 1968; Rabiner, Goldfine, Hart, Summaria, and Robbins, 1969). Both these studies demonstrate that it is possible to measure plasminogen immunologically but the methods described are time consuming and not available for routine laboratories. Haemagglutination inhibition techniques have been used to assay many proteins and are based on the original work of Salk (1944) and Boyden (1951) and later developed by many workers; red cells coated with Received for publication 18 July 1970. antigen are agglutinated by appropriate antiserum $\stackrel{\supset}{\supset}$ and this agglutination can be inhibited by homo- $\vec{c}$ logous antigen (Hebert, 1967).

This study was undertaken in order to devise a haemagglutination inhibition assay for plasminogen that, whilst being accurate, reproducible, and with a high sensitivity, would also be simple and quick. Investigations were performed to find the optimum $\frac{}{\circ}$ conditions for coating the cells with plasminogen 2 and their subsequent use for performing the assay. $\overrightarrow{0}$

\section{Materials}

BUFFERS

1 Phosphate buffer was prepared by mixing 350 parts of $\mathrm{Na}_{2} \mathrm{HPO}_{4}(0 \cdot 15 \mathrm{M})$ to 65 parts of $\mathrm{KH}_{2} \mathrm{PO}_{4}$ $(0 \cdot 15 \mathrm{M})$ and the $p \mathrm{H}$ adjusted to $6 \cdot 4$. For experiments using the buffer at different $p \mathrm{Hs}$ the ratio $\mathrm{Na}_{2} \mathrm{HPO}_{4} / \beta$ $\mathrm{KH}_{2} \mathrm{PO}_{4}$ was varied.

2 Citrate buffer was made by adding to 1 volume of phosphate buffer an equal volume of trisodiumo citrate $(0 \cdot 15 \mathrm{M})$.

The buffers were stored at $4^{\circ} \mathrm{C}$.

FORMALDEHYDE SOLUTION BP ${ }^{1}$

A $3 \%(\mathrm{v} / \mathrm{v})$ solution was made in normal saline ando the $p \mathrm{H}$ was adjusted to $7 \cdot 20-7 \cdot 25$ with $0 \cdot 1 \mathrm{~N} \mathrm{NaOH}_{6}$

PLASMINOGEN ${ }^{2}$

Ten to 15 caseinolytic units/mg protein are dissolved in distilled water and stored in aliquots at $-40^{\circ} \mathrm{C}$.

'Evans Medical Ltd., Liverpool

'Kabi Pharmaceuticals Ltd., Stockholm 
PLASMINOGEN ANTISERUM $(\mathrm{A} / \mathrm{s})^{3}$

This is stored as a $1 / 50$ dilution in diluting fluid in aliquots at $-40^{\circ} \mathrm{C}$ and made up to $1 / 250$ dilution for routine assay.

\section{DILUTING FLUID}

Heated pooled rabbit serum ${ }^{4}$ was incubated at $37^{\circ} \mathrm{C}$ for 30 minutes with an equal volume of washed packed sheep red blood cells to remove naturally occurring anti-sheep red blood cell substances. The adsorbed serum was added to citrate buffer to give a final concentration of $1 \%$ (unless otherwise stated). To this was added sodium azide, as a preservative, to give a final concentration of $1 \mathrm{mg} / \mathrm{ml}$.

\section{EUGLOBULIN}

The preparation of euglobulin was based on a technique described by Cash (1966). It was precipitated in a silicone-lined centrifuge tube from 1 volume of plasma at $4^{\circ} \mathrm{C}$ by adding 19 volumes of euglobulin precipitant. The $p \mathrm{H}$ was adjusted to 6.0 and after 10 minutes the solution was centrifuged at $2,000 \mathrm{~g}$ for 10 minutes. The precipitate was suspended in 1 volume of citrate buffer.

\section{Methods}

\section{FIXING OF CELLS WITH FORMALDEHYDE OR} GLUTERALDEHYDE

The sheep red blood cells ${ }^{4}$ were washed three times in approximately 50 volumes of $0.9 \%$ saline. The packed cells volume was measured after centrifugation at $1,000 \mathrm{~g}$ for five minutes. The details of the formalization technique have been described by Das (1970). Alternatively, gluteraldehyde ${ }^{5}$-fixed cells were prepared by the method of Bing, Weyand, and Stavitssky (1967).

\section{TANNING}

The formaldehyde or gluteraldehyde-treated cells were washed three times in 50 volumes of phosphate buffer followed by three washings in 50 volumes of distilled water. To a $2 \%$ suspension of phosphate buffer was added an equal volume of freshly made $1 / 40,000$ tannic $a^{2} d^{6}$ solution $(w / v)$ in the same buffer. The mixture was incubated in a water bath at $56^{\circ} \mathrm{C}$ for one hour, with gentle mixing every 10 minutes.

\section{COATING}

After washing the tanned cells three times in $\mathbf{5 0}$ volumes of phosphate buffer a $2 \%$ suspension was

\footnotetext{
${ }^{3}$ Behringwerke AG, West Germany

'Wellcome Reagents Ltd., Beckenham

${ }^{5}$ Koch Light Laboratories Ltd., Colnbrook

May and Baker Ltd., Dagenham
}

made in citrate buffer and an equal volume of plasminogen solution $(20 \mu \mathrm{g} / \mathrm{ml})$ in citrate buffer was added. After incubation at $37^{\circ} \mathrm{C}$ for one hour the cells were washed three times in citrate buffer.

STORAGE OF SENSITIZED CELLS

A $2.5 \%(\mathrm{v} / \mathrm{v})$ suspension of the cells was made in diluting fluid and stored at $4^{\circ} \mathrm{C}$. After three or four days, when the cells had settled, the supernatant was decanted and replaced by an equal volume of fresh diluting fluid. Aliquots of $2.5 \mathrm{ml}$ were made for daily use.

\section{ANTIBODY TITRATION}

To each well in a microtitre $U$ plate ${ }^{7}$ was added 1 volume of diluting fluid ( 1 volume $=0.025 \mathrm{ml})$; 1 volume of antiserum was placed in the first cup and serially doubly diluted and 1 volume of $2.5 \%$ sensitized cells was added to each cup. A negative control consisted of 1 volume of diluting fluid and 1 volume of cells. After shaking the plates were incubated overnight at $4^{\circ} \mathrm{C}$. Agglutination was demonstrated by a smooth mat of cells at the bottom of the well; this was described as positive $(+)$, while if there was no agglutination a button formed in the centre at the bottom of the well and this was called negative $(-)$. Intermediate reactions were recorded as $( \pm)$. When assaying the cells the end point titre was the lowest concentration of antiserum which produced complete agglutination in the microtitre plate.

\section{HAEMAGGLUTINATION INHIBITION ASSAY}

To each cup in the microtitre plate was added 1 volume of diluting fluid. Five equally spaced dilutions of the sample were made and 1 volume of each was placed in adjacent cups which were then serially doubly diluted. One volume of antiserum $(1 / 250)$ was added to each cup and the plates were left for four hours at $4^{\circ} \mathrm{C}$ before 1 volume of a $2.5 \%$ suspension of sensitized cells was added to each well. After incubation overnight at $4^{\circ} \mathrm{C}$ the results were recorded. The end point was taken as the well with the highest dilution of sample in which no agglutination could be seen.

Positive and negative controls, known standards of purified plasminogen, and reference euglobulin were included in each experiment. The plasminogen concentrations obtained by the haemagglutination inhibition assay are described as haemagglutination inhibition units (HIU) and were calculated as follows:

Sensitivity $=$ concentration of purified plasminogen of standard $\times$ titre of standard

and therefore

'Cooke Engineering Co., USA 
concentration of plasminogen in sample (HIU) $=$ sensitivity/titre of sample.

(The plasminogen content of the standard was measured by the caseinolytic method.)

\section{CASEINOLYTIC ASSAY}

This was based on the technique of Remmert and Cohen (1949) as modified by Alkjaersig et al (1959) and values obtained are designated caseinolytic units.

\section{Results}

\section{TANNING STAGE}

Table I shows the effect of increasing tannic acid concentration. The cells were subsequently coated at plasminogen concentrations given in the Table under standard conditions. As can be seen the sensitivity of the coated cells was not significantly influenced by tannic acid concentrations between $1 / 20,000$ and $1 / 80,000$.

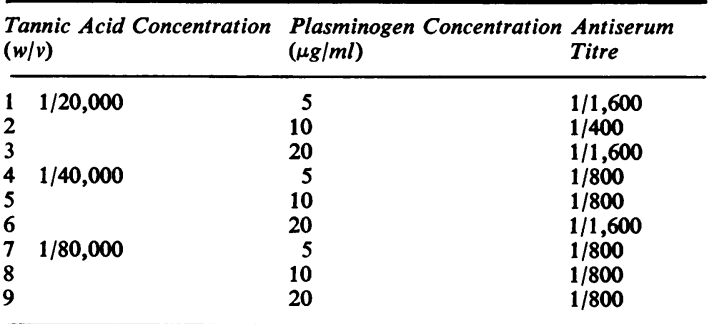

Table I Titre of antiplasminogen serum against cells prepared at different tannic acid and plasminogen concentrations (cells in diluting fluid with rabbit serum concentration $0.8 \%$ )

\section{COATING STAGE}

Increasing the concentration of plasminogen during the coating procedure tended to increase the sensitivity of the cells (Table I). At higher concentrations of the antigen, however, there was a tendency to spontaneous autoagglutination.

The cells could be coated successfully between

\begin{tabular}{ll}
\hline $\mathrm{p} H$ & Titre of Antiserum \\
\hline $4 \cdot 0$ & $1 / 1,600$ \\
$5 \cdot 0$ & $1 / 3,200$ \\
$6 \cdot 0$ & $1 / 3,200$ \\
$6 \cdot 4$ & $1 / 1,600$ \\
$7 \cdot 0$ & $1 / 800$ \\
\hline
\end{tabular}

Table II Titre of antiplasminogen serum against cells coated with plasminogen at different $\mathrm{pH}$ levels
pH 4 and $p \mathrm{H} 7$ and Table $I I$ shows the antiseru绾 titre at various $p H$ levels. In the routine assay celis were coated at $p \mathrm{H} 6 \cdot 4$. The sensitized cells can be stored at $4^{\circ} \mathrm{C}$ for at least eight months without lo of activity.

\section{SPECIFICITY}

The substances listed in Table III failed to demonstrate any interference with the reaction. They wefe added to the haemagglutination inhibition syste $\vec{m}$ in concentrations similar to those found physiologit cally or used pharmacologically. They neithgis inhibited the agglutination reaction at an antiserum concentration of $1 / 500$, nor did they cause agglutin tion of the sensitized cells in the absence of antit serum.

\begin{tabular}{lll}
\hline Substance & Concentration \\
\hline Gamma globulin & $1 \mathrm{~g} / 100 \mathrm{ml}$ \\
Albumin & $4 \mathrm{~g} / 100 \mathrm{ml}$ \\
Trasylol & $100 \mathrm{Kallikrein}$ inactivator units $/ \mathrm{ml}$ \\
EACA & $10^{-5}$ & International Units $/ \mathrm{ml}$ \\
Heparin & Neat \\
Normal rabbit serum (heated) & N
\end{tabular}

Table III Substances not interfering with haemago glutination inhibition assay in concentrations stated

\section{INHIBITION OF THE AGGLUTINATION}

REACTION

The reaction between antibody and sensitized cells could be specifically inhibited by purified plas minogen, plasma, serum, and euglobulin. Figures and 2 show that the degree of inhibition was proporo tional to the caseinolytic activity $(\mathrm{r}=1 \cdot 00, \mathrm{P}$ $0.001 ; r=0.99, P<0.001)$. The intercept on the $\frac{\rho}{9}$ axis in Fig. 2 represents the sensitivity of the method Figure 3 illustrates the linear correlation between antiserum concentration and the inhibition titre $(\mathrm{r}=1.00, \mathrm{P}<0.001)$.

\section{COMPARISON OF HAEMAGGLUTINATION} INHIBITION AND CASEINOLYTIC ASSAYS Thirty-five samples of euglobulin were assayed both by the haemagglutination inhibition assay and by the caseinolytic method. The results are given in Fig. 4 which shows a good correlation between the two methods. The position of the line was calculate by a least squares regression $(r=0.90,<P 0.0010$

\section{REPRODUCIBILITY}

A single sample of euglobulin was assayed 24 times on a single day: mean $=6.88 \mathrm{HIU}$, standard devia? tion $(\mathrm{SD})=0.68$. The inter-day variation of the assay technique was investigated by assaying on sample of euglobulin 10 times each day for five dayso 


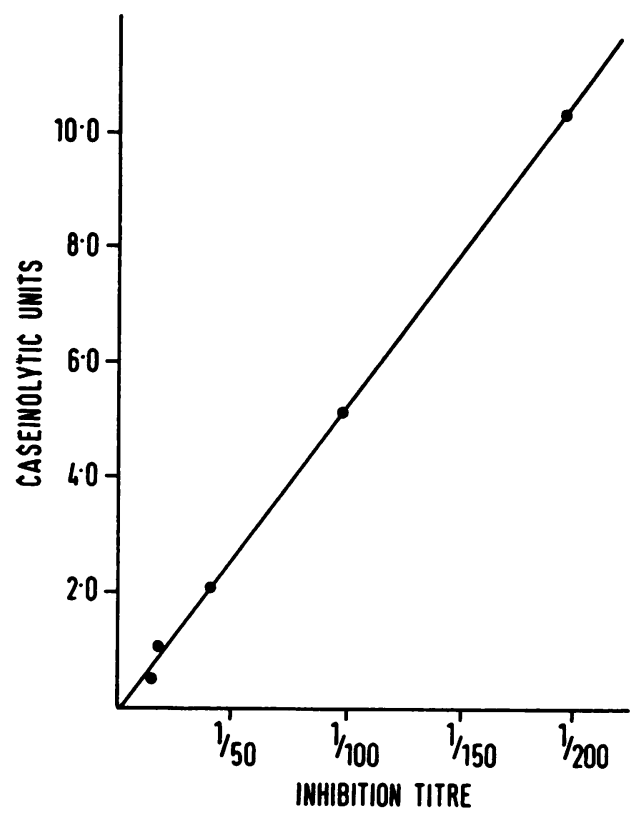

Fig. 1. Correlation between caseinolytic and haemagglutination assays, using a purified plasminogen sample, performed simultaneously by the two techniques.

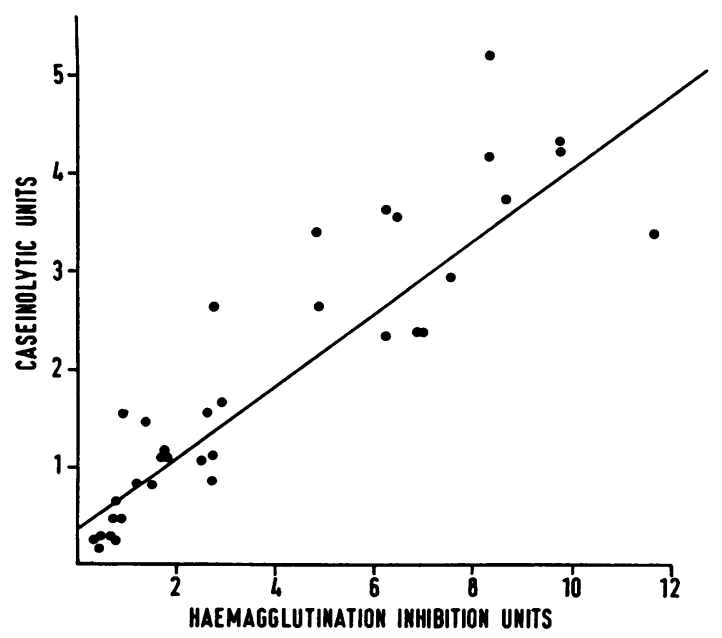

Fig. 4. Comparison of the plasminogen concentration in 35 euglobulin samples measured simultaneously by haemagglutination and caseinolytic assays.

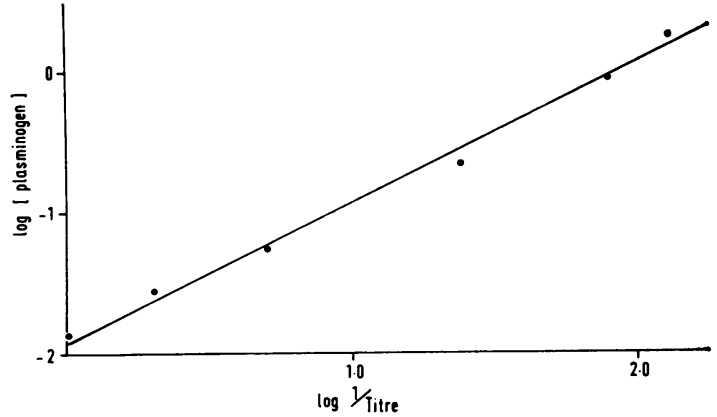

Fig. 2. Correlation between plasminogen concentration (caseinolytic units/ml) and haemagglutination inhibition titre using a sample of euglobulin.

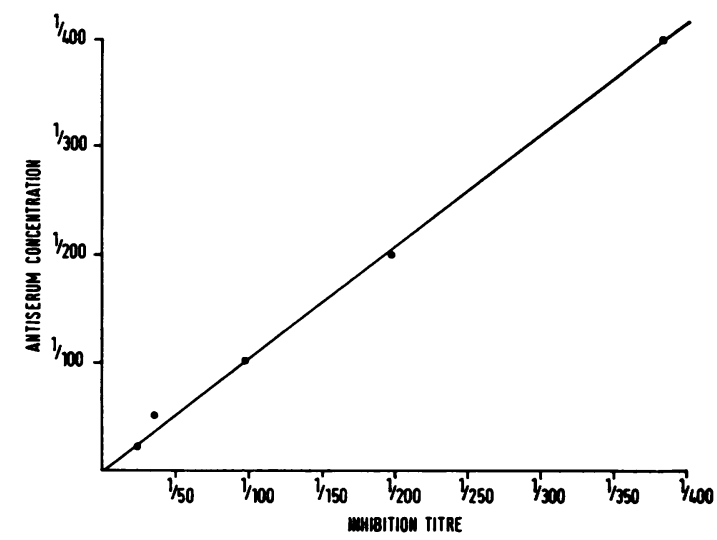

Fig. 3. Variation of inhibition titre with antiserum concentration using a constant amount of plasminogen. 
mean of the daily means $=7 \cdot 52 \mathrm{HIU}, \mathrm{SD}$ of means $=0.45$.

\section{Discussion}

This assay is based on the specificity of a plasminogen-anti-plasminogen antiserum reaction. Although Robbins, Summaria, Elwyn, and Barlow (1965) have shown by moving-boundary electrophoresis that their purified plasminogen is not homogeneous, they emphasize that the small components suggesting a heterogeneous mixture may be artifact, either subunits or peptide fragments, and do not represent true multi-molecular forms of plasminogen as has been reported in dogs (Hererlein and Barnhart, 1967). This was confirmed by finding only a single precipitation band on immunodiffusion. Agglutination of sensitized cells by antisera is inhibited by purified plasminogen, plasma, serum, and euglobulin (Fig. 5) but not by gamma globulin, albumin, or rabbit serum. This demonstrates the specificity of the system and the latter observation is in keeping with the experiments of Rabiner et $a \stackrel{\vec{E}}{\overrightarrow{0}}$ (1969), who demonstrated little or no cross reactivity with other species of animal. Quantitative studies $\overrightarrow{\vec{s}}$ with purified plasminogen and euglobulin have + shown that the end point is proportional to the plasminogen concentration, and inversely proportional to the antisera concentration (Figs. 1-4).

All these observations suggest that this assay system is both quantitatively and qualitatively suit-œ able for measuring plasminogen. Two problems $\overrightarrow{0}$ arose when the haemagglutination inhibition assay was used to measure the plasminogen content of plasma. First a heterophile antibcdy (Salo, 1966) present in plasma interfered with the inhibition? reaction. Although this nonspecific agglutination could be adsorbed out by incubating the plasma with? plasminogen-coated cells, or by formaldehyde- or $\vec{\omega}$ gluteraldehyde-prepared cells, the latter had such an avidity for plasminogen that they removed significant ${ }^{-}$ amounts from the plasma. Secondly the values for $\vec{z}$ haemagglutination inhibition obtained with plasma correlated poorly with the caseinolytic assay. To $\stackrel{\widehat{S}}{-}$

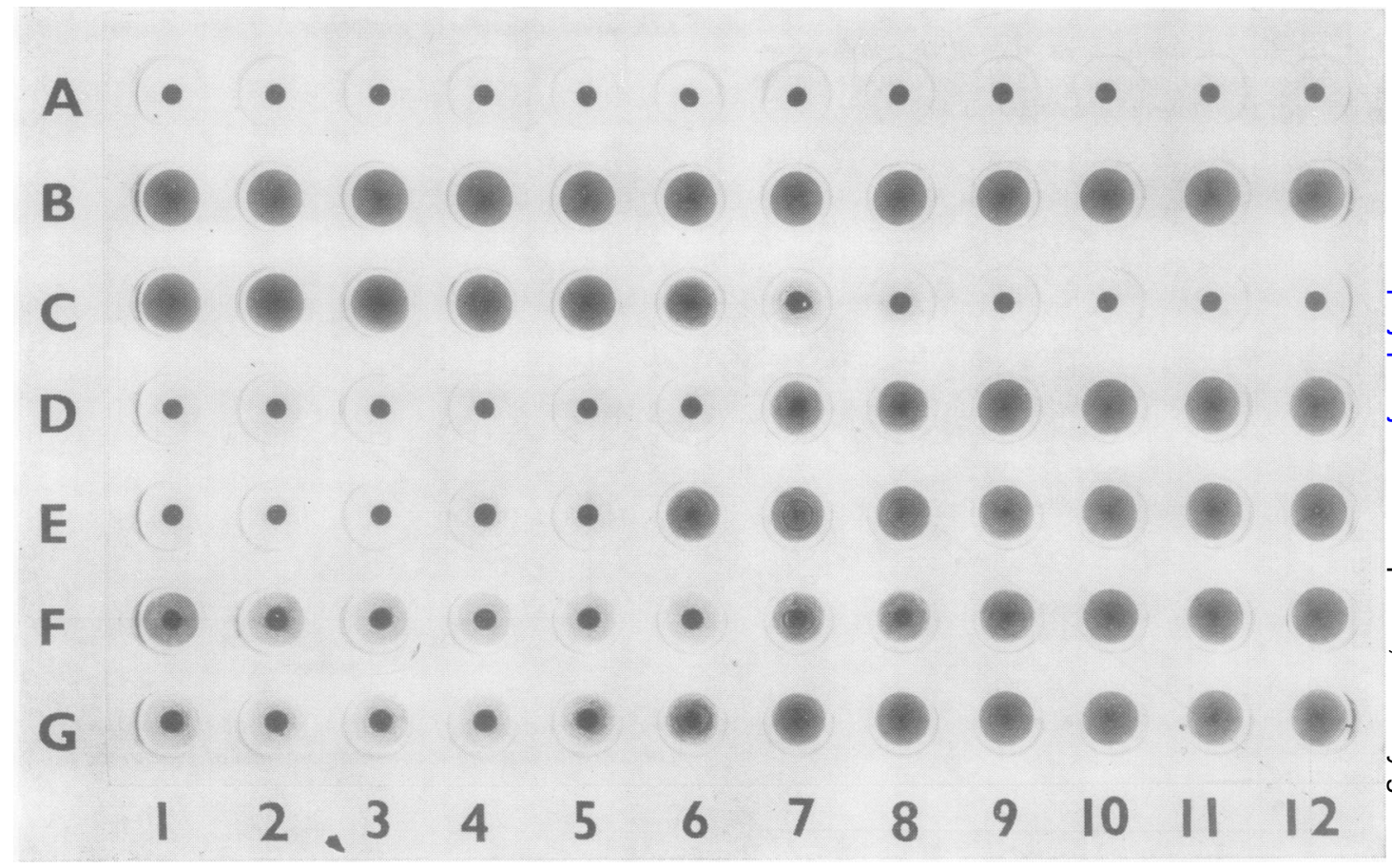

Fig. 5. Microtitre plate showing negative controls (row A) and positive controls (row B). Row C: titration of cells with decreasing concentrations of antiserum from left 1/100,1/200,1/400, etc, end point 1/1,600 (cup 5).

Agglutination, with $1 / 400$ antiserum, was inhibited in rows $D$ and $E$ with two different concentrations of purified plasminogen, and in rows $F$ and $G$ with two samples of euglobulin; dilutions of plasminogen containing samples in these rows: $1 / 12,1 / 18,1 / 24,1 / 36$, etc, end points $1 / 72,1 / 48,1 / 72$, and $1 / 36$ respectively. 
overcome these difficulties euglobulin was used; as the plasminogen content of this cryoprecipitate is approximately equal to that in plasma (Kline, 1966), it is easy to prepare and does not require to be adsorbed as the heterophile antibody is diluted out before the end point is reached. As Fig. 4 shows, a good correlation between the two methods was found and compares favourably with that of Rabiner et al (1969), using acid-treated plasma and of Ganrot and Niléhn (1968) with an immunodiffusion technique. The correlation coefficients found with these techniques are very similar and may represent the maximum obtainable. Although the regression line intersects the caseinolytic axis (Fig. 4), the haemagglutination inhibition assay can be used to measure very small quantities of plasminogen (Fig. 2). The tanned red cell method, like other immunological assays, gave plasminogen concentrations approximately twice that with the caseinolytic assay.

This technique was devised to try to overcome some of the many problems encountered with enzymological assays of plasminogen. Current techniques attempt to obtain maximum activation of plasminogen with minimum inhibition of the plasmin created by antiplasmins. As plasmin in the presence of excess activator is inhibited and because people differ in their antistreptolysin $O$ titres, it is necessary to titrate the activator against plasminogen (Hummel, Buck, and de Renzo, 1966). Acid is used to destroy antiplasmins, but this inactivation may not be complete (Jocobsen, 1964), and if this is done with high concentrations of acid it is possible that some of the plasminogen may be destroyed (Berg et al, 1966; Wolf, 1968). None of the enzymic assays use native fibrin as it is contaminated with plasminogen and they therefore depend upon unnatural substrates like heated fibrinogen, casein, or esters. None of these difficulties are encountered with immunological assays.

Thus this haemagglutination inhibition assay is less time consuming than any method currently available. The immunodiffusion technique requires preparative electrophoresis followed by antigenantibody crossed electrophoresis, while for the radioimmunoassay plasminogen must be isotopically labelled, the antigen-antibody mixture must incubate for 72 hours, and an expensive scintillation counter is required (Hererlein and Barnhart, 1967; Rabiner et al, 1969). The time taken to perform the haemagglutination inhibition assay can be reduced by incubating the antigen and antiserum for a shorter time but this tends to reduce the sensitivity of the technique. After the sensitized cells have been added it is often possible to read the end point after about an hour. The sensitivity of the caseinolytic technique is approximately $0.1 \mathrm{CU} / \mathrm{ml}$ whereas the haemag- glutination inhibition assay can detect as little as $0.013 \mathrm{CU} / \mathrm{ml}$ (or $3 \times 10^{-4} \mathrm{CU}$ as only $0.025 \mathrm{ml}$ of sample is required). With this technique many samples can be assayed together quickly; the method is economical and simple, requiring no expensive apparatus, and the reproducibility compares favourably with that of other techniques.

The authors wish to thank Dr R. A. Cumming, Director, South-East Scotland Blood Transfusion Centre, Edinburgh, for providing the facilities for this work, and Dr J. D. Cash who initiated this project. This work was supported by the Scottish National Blood Transfusion Association and the Scottish Hospitals Endowment Research Trust.

\section{References}

Alkjaersig, N., Fletcher, A. P., and Sherry, S. (1959). The mechanism of clot dissolution by plasmin. J. clin. Invest., 38, 1086-1095.

Basu, H. K. (1969). Fibrinolysis and abruptio placentae. J. Obstet. Gynaec. Brit. Cwlth, 76, 481-496.

Berg, W., Korsan-Bengtsen, K., and Ygge, J. (1966). Determination of plasminogen in human plasma by the lysis time method. Thrombos Diathes. haemorrh. (Stuttg.), 16, 1-17.

Bing, D. H., Weyand, J. G. M., and Stavitsky, A. B. (1967). Hemagglutination with aldehyde-fixed erythrocytes for assay of antigens and antibodies. Proc. Soc. exp. Biol. (N.Y.), 124, $1166-1170$.

Boyden, S. V. (1951). The adsorption of proteins on erythrocytes treated with tannic acid and subsequent hemagglutination by anti-protein sera. J. exp. Med., 93, 107-120.

Cash, J. D. (1966). Effect of moderate exercise on the fibrinolytic system in normal young men and women. Brit. med. J., 2, 502-506.

Das, P. C. (1970). Investigations and preparation of fibrinogen-coated tanned sheep red cells. J. clin. Path., 23, 149-155.

Ganrot, P. O., and Niléhn, J. E. (1968). Immunochemical determination of human plasminogen. Clin. chim. Acta, 22, 335-340.

Hebert, W. J. (1967). Passive haemagglutination. In Handbook of Experimental Immunology, edited by D. M. Weir. Blackwell, Oxford.

Hererlein, P. J., and Barnhart, M. I. (1967). Multimolecular forms of profibrinolysin revealed by a zymogram technique. Biochim. biophys. Acta (Amst.), 147, 609-612.

Hummel, B. C. W., Buck, F. F., and Renzo, E. C. de (1966). Interaction of streptokinase and human plasminogen. III. Plasmin and activator activities in reaction mixtures of streptokinase and human plasminogen of various molar ratios. J. biol. Chem., 241, 3474-3479.

Jocobsen, C. D. (1964). The caseinolytic method for determination of plasminogen-plasmin in human plasma and serum. Scand. J. clin. Lab. Invest., 16, 372-382.

Kline, D. L. (1966). Plasminogen and proactivator concentration in human plasma. Proc. Soc. exp. Biol. (N.Y.), 121, 184-186.

McKay, D. G. (1965). Disseminated Intravascular Coagulation: an Intermediary Mechanism of Disease. Hoeber, Harper and Row, New York.

Pechet, L. (1965). Fibrinolysis. New Engl. J. Med., 273, 966-973 and 1024-1034.

Rabiner, S. F., Goldfine, I. D., Hart, A., Summaria, L., and Robbins, K. C. (1969). Radio immunoassay of human plasminogen and plasmin. J. Lab. clin. Med., 74, 265-273.

Remmert, L. F., and Cohen, P. P. (1949). Partial purification and properties of a proteolytic enzyme of human serum. J. biol. Chem., 181, 431-448.

Robbins, K. C., Summaria, L., Elwyn, D., and Barlow, G. H. (1965) Further studies on the purification and characterization of human plasminogen and plasmin. J. biol. Chem., 240, 541-550. 
Roberts, P. S. (1958). Measurement of the rate of plasmin action on synthetic substrates. J. biol. Chem., 232, 285-291.

Salk, J. E. (1944). A simplified procedure for titrating hemagglutinating capacity of influenza-virus and the corresponding antibody. J. Immunol., 49, 87-98.

Salo, O. P. (1966). Studies of heteroagglutination in human sera with special reference to infectious mononucleosis. Ann. Med. exp. Fenn., 44, Suppl. 1.

Sherry, S. (1968). Fibrinolysis. Ann. Rev. Med., 19, 247-268.
Troll, W., Sherry, S., and Wachman, J. (1954). The action of plasmin on synthetic substrates. J. biol. Chem., 208, 85-93.

Wolf, P. (1968). Modification of fibrin agar plate for measurements of the components of the fibrinolytic system. 1. The measurement of plasminogen (on type 1 fibrin agar plates). Thrombos. $f$ Diathes. haemorrh. (Stuttg.), 20, 50-65.

Ygge, J. (1970). Studies on blood coagulation and fibrinolysis in conditions associated with an increased incidence of thrombosis. Scand. J. Haemat., Suppl. 11.

\section{Reports and Bulletins prepared by the Association of Clinical Biochemists}

The following reports and bulletins are published by the Association of Clinical Biochemists. They may be obtained from The Administrative Office, Association of Clinical Biochemists, 7 Warwick Court, Holborn, London, WC1R 5DP. The prices include postage, but airmail will be charged extra. Overseas readers should remit by British Postal or Money Order. If this is not possible the equivalent of $50 \mathrm{p}$ is the minimum amount that can be accepted.

SCIENTIFIC REPORTS

3 Automatic Dispensing Pipettes. An assessment of 35 commercial instruments 1967 P. M. G. BROUGHTON, A. H. GOWENLOCK, G. M. WIDDOWSON, and K. A. AHLQUIST $85 \mathrm{p}(\$ 2)$

4 An Evaluation of 5 Commercial Flame Photometers suitable for the Simultaneous Determination of Sodium and Potassium March 1970 P. M. G. BROUGHTON and J. B. DAWSON $85 \mathrm{p}(\$ 2)$

\section{TECHNICAL BULLETINS}

9 Determination of Urea by AutoAnalyzer November

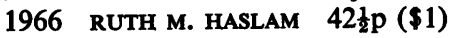

10 Filter Fluorimeters. A comparative list of 14 instruments March 1967 HANNELORE BRAUNSBERG (Reissued in response to demand. Text still valuable, list now out of date) $42 \frac{1}{2} p(\$ 1)$

11 Determination of Serum Albumin by AutoAnalyzer using Bromocresol Green October 1967 B. E. NORTHAM and G. M. WIDDOWSON $42 \frac{1}{2} \mathrm{p}$ (\$1)

13 An Assessment of the Technicon Type II Sampler Unit March 1968 B. C. GRAY AND G. K. MCGOWAN $42 \frac{1}{2} p(\$ 1)$
14 Atomic Absorption Spectroscopy. An outline of its principles and a guide to the selection of instruments May 1968 J. B. DAWSON and P. M. G. BROUGHTON $42 \frac{1}{2} \mathrm{p}(\$ 1)$

15 A Guide to Automatic Pipettes (2nd edition) June 1968 P. M. G. BROUGHTON $42 \frac{1}{2} p(\$ 1)$

16 A Guide to Automation in Clinical Chemistry May

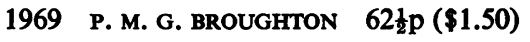

17 Flame Photometers (2nd edition) 1969 P. WILdING $62 \frac{1}{2} \mathrm{p}(\$ 1.50)$

18 Control Solutions for Clinical Biochemistry (4th $\bar{\partial}$ edition) March 1970 P. M. G. BROUGHTON $62 \frac{1}{2} \mathrm{p}$ $(\$ 1.50)$

19 Spectrophotometers. A comparative list of low-priced instruments readily available in Britain May 1970 C. E. WILDE and P. SEWELL $62 \frac{1}{2} \mathrm{p}(\$ 1.50)$

20 Quantities and Units in Clinical Biochemistry June 1970 P. M. G. BROUGHTON $62 \frac{1}{2} \mathrm{p}(\$ 1.50)$ More than 30 copies in units of 10 at $20 p$

21 Filter Fluorimeters: A comparative list of 18 instruments September 1970 H. BRAUNSBERG and S. S. BROWN $62 \frac{1}{2} \mathrm{p}(\$ 1.50)$ 